\title{
OPTIMALISASI PENYUSUNAN MENU DIET PENDERITA STROKE DENGAN METODE GOAL PROGRAMMING
}

\author{
Ni Made Dinda Pratiwi ${ }^{1}$, G.K. Gandhiadi ${ }^{2}$, Ni Ketut Tari Tastrawati ${ }^{3}$ \\ ${ }^{1}$ Program Studi Matematika, Fakultas MIPA - Universitas Udayana [Email: nimadedindapratiwi@gmail.com] \\ ${ }^{2}$ Program Studi Matematika, Fakultas MIPA - Universitas Udayana [Email: gandhiadi@ unud.ac.id] \\ ${ }^{3}$ Program Studi Matematika, Fakultas MIPA - Universitas Udayana [Email: tastrawati@unud.ac.id] \\ ${ }^{\S}$ Corresponding Author
}

\begin{abstract}
Stroke is a disorder of brain nerve function caused by blockage of blood circulation to the brain. In preparing the diet for stroke, it is possible to deviate from the recommended nutritional value and total energy. This problem could be overcome by compiling a stroke diet menu using the Goal programming method. The purpose of this study is to determine whether the results of the portion of food obtained using the Goal programming method can meet the recommended energy and nutritional content targets, as well as knowing the percentage of total energy content produced per day from the preparation of the diet menu to the recommended total energy content. The calculations in this study using the help of LINGO software with the results that the diet menu by Goal programming method has met the recommended nutrients and energy from the standard stroke diet at Klungkung Hospital, and the percentage of energy fulfilled from the stroke IIB diet for three days shows a 100\% result.
\end{abstract}

Keywords: Diet Menu, Goal programming, Optimization, Stroke

\section{PENDAHULUAN}

Stroke merupakan suatu gangguan fungsi saraf otak akibat tersumbatnya peredaran darah ke otak yang menyebabkan gangguan fungsional otak fokal maupun global yang berlangsung lebih dari 24 jam (kecuali ada intervensi bedah atau membawa kematian), dan tidak disebabkan oleh sebab lain selain penyebab vaskuler (WHO, 2016). Stroke menjadi penyebab kematian utama di Indonesia (Kemenkes RI, 2019). Prevalensi atau jumlah kasus penyakit stroke di Indonesia pada tahun 2018 mengalami peningkatan sebesar 3,9 per mil jika dibandingkan dengan tahun 2013 dengan sebagian besar kasusnya dialami oleh penduduk laki-laki pada kelompok usia 75 tahun ke atas (Kemenkes RI, 2013, 2018). Peningkatan ini umumnya diakibatkan oleh pola hidup yang tidak sehat. Untuk mengatasi keadaan tersebut, perlu dilakukan tindakan pencegahan stroke dengan memperbaiki kebiasaan hidup yang tidak sehat tersebut.

Pengaturan pola makan atau biasa disebut diet merupakan salah satu pengobatan yang dianjurkan oleh dokter. Secara umum energi yang dibutuhkan bagi penderita stroke adalah sekitar 25-45 kkal/kg BBI (PERSAGI \& ADI, 2019). Diet Stroke secara umum dibagi menjadi dua jenis, yaitu diet Stroke I untuk penderita akut, dan diet Stroke II untuk penderita yang sedang dalam masa pemulihan. Menu diet stroke di rumah sakit biasanya disusun dengan bantuan metode Bahan Makanan Penukar. Metode Bahan Makanan Penukar (BMP) merupakan metode penyusunan menu makanan dengan menggunakan penggolongan makanan berdasarkan nilai gizi yang setara (Almatsier, 2004). Namun, perhitungan kandungan gizi yang dilakukan dengan metode ini dapat mengalami penyimpangan terhadap nilai gizi yang dianjurkan. Sehingga perlu adanya suatu metode penyelesaian masalah yang dapat digunakan untuk menyelesaikan masalah penyimpangan terhadap nilai-nilai gizi atau dengan kata lain memiliki tujuan yang lebih dari satu. Salah satu metodenya adalah metode goal programming. Metode goal programming merupakan suatu metode untuk menyelesaikan permasalahan optimasi baik memaksimalkan atau meminimalkan masalah yang memiliki 
lebih dari satu sasaran yang hendak dicapai (Siswanto, 2007).

Penyusunan menu diet sebelumnya maslah penentuan menu diet pernah dilakukan oleh Santika (2009). Penelitiannya berupa penggunaan aplikasi linear programming dan untuk menentukan menu diet bagi anak-anak berusia 9 hingga 11 bulan di Kabupaten Bogor di Indonesia dan untuk mengidentifikasi nutrisi yang kemungkinan akan tetap rendah dalam diet mereka. Selain itu, Mustafa (2017) pernah melakukan penelitian tentang optimalisasi menu diet sehat dengan menggunakan algoritma genetika. Penelitian ini telah menghasilkan sebuah system optimalisasi menu makan diet sehat menggunakan Algoritma Genetika. Algoritma Genetika ini mampu menghasilkan solusi yang memenuhi kriteria tanpa harus mengevaluasi seluruh kemungkinan solusi yang ada. Hasil akhir dari sistem ini adalah terbentuknya jadwal menu makan terbaik dalam 30 hari dari 450 pangkat 90 kombinasi. Metode goal programming juga digunakan untuk melakukan penyusunan menu diet oleh Dhoruri (2017). Dalam penelitiannya, penyusunan menu diet dilakukan bagi penderita diabetes melitus di Rumah Sakit PKU Muhammadiah Yogyakarta. Pada penelitiannya diperoleh hasil bahwa kandungan gizi dari diet yang diolah dengan metode tersebut telah memenuhi energi dan zat gizi yang direkomendasikan.

Berdasarkan hal tersebut penelitian ini memiliki tujuan untuk mengetahui hasil porsi makanan yang diperoleh dengan menggunakan metode goal programming sesuai dengan tujuan yang hendak dicapai, yaitu dengan meminimalkan penyimpangan energi, karbohidrat, lemak dan protein.

\section{METODE PENELITIAN}

\section{Jenis dan Sumber Data}

Jenis data yang digunakan dalam penelitian ini adalah data sekunder. Data sekunder yang digunakan berupa daftar bahan makanan penukar, data asuhan gizi penderita stroke dan standar diet stroke II yang sudah disesuaikan dengan gizi dari RSUD Klungkung. Pada penyusunan menu diet, pemberian makan akan dibagi menjadi enam, yaitu sarapan, selingan pagi, makan siang, selingan sore, makan malam dan selingan malam.

\section{Metode Analisis Data}

Tahapan analisis data pada penelitian ini adalah sebagai berikut:

1) Menyusun menu diet dengan metode Bahan Makanan Penukar (BMP) dengan tahapan sebagai berikut:

a. Menentukan jumlah kebutuhan energi/ kalori.

b. Menghitung batas atas dan batas bawah dari karbohidrat, lemak dan protein yang sesuai dengan jumlah energi yang sesuai.

c. Menentukan menu diet stroke berdasarkan daftar bahan makanan penukar yang sesuai dengan standar diet dari RSUD Klungkung.

2) Memformulasi model goal programming, dengan langkah-langkah sebagai berikut

a. Menentukan variabel keputusan

b. Melakukan perumusan fungsi sasaran goal programming dalam menyusun menu diet stroke

c. Merumuskan fungsi tujuan

3) Melakukan perhitungan goal programming dengan bantuan software LINGO.

4) Melakukan interpretasi hasil

\section{HASIL DAN PEMBAHASAN}

Studi kasus yang digunakan dalam penelitian ini adalah penyusunan menu diet Stroke II bagi salah satu penderita stroke. Penderita merupakan seorang wanita berusia 53 tahun dengan berat badan $65 \mathrm{~kg}$, tinggi badan $160 \mathrm{~cm}$ dan Berat Badan Ideal (BBI) sebesar 54 $\mathrm{kg}$. Penderita tidak mengalami penyakit komplikasi lainnya dan tidak memiliki alergi terhadap makanan. Selanjutnya dilakukan langkah-langkah sesuai tahapan analisis data.

\subsection{Penyusunan Menu Diet dengan Metode Bahan Makanan Penukar}

Terlebih dahulu ditentukan jumlah kebutuhan energi/kalori dari penderita stroke. Perhitungan kebutuhan energi total ini akan berbeda tiap orangnya, tergantung pada berat badan, tinggi badan penderita serta kondisi penderita saat dilakukan pengamatan. Namun untuk perhitungan disesuaikan juga dengan data asuhan gizi dari penderita. Berdasarkan data asuhan gizi penderita stroke, diperoleh bahwa perhitungan kebutuhan pasien dihitung berdasarkan diet stroke dengan kebutuhan energi 35kkal $/ \mathrm{kgBBI}$. Maka diperoleh kebutuhan energi total $=35 \mathrm{kkal} / \mathrm{kgBBI} \times$ 
$54 \mathrm{~kg}=1.890 \mathrm{kkal} . \quad$ Sehingga kandungan energi total yang direkomendasikan adalah $1.890 \mathrm{kkal}$.

Berdasarkan PERSAGI \& ADI (2019), proporsi zat gizi yang disarankan bagi penderita stroke adalah $60-70 \%$ dari total energi, lemak $20-25 \%$ dari kebutuhan energi total protein sebesar $0,8-1,5 \mathrm{~g} / \mathrm{kg} \mathrm{BBI}$, kolesterol diberikan $<300 \mathrm{mg}$ per hari, cairan 6-8 gelas per hari dan natrium dibatasi dengan pemberian 5 gram garam dapur perharinya. Namun, dalam penelitian ini, zat gizi yang digunakan adalah zat gizi karbohidrat, protein, dan lemak. Kandungan gizi lain seperti natrium, kolesterol dan cairan diabaikan. Hal ini disebabkan karena pada data daftar bahan makanan penukar, zat gizi yang tersedia hanya karbohidrat, protein dan lemak. Sehingga batas-batas kandungan gizinya adalah:

a. Kandungan Karbohidrat

Batas atas $\left(\mathrm{U}_{2}\right)=70 \% \times \frac{1890}{4}=330,75 \mathrm{~g}$
Batas bawah $\left(\mathrm{L}_{2}\right)=60 \% \times \frac{1890}{4}=283,5 \mathrm{~g}$

b. Kandungan Protein

Batas atas $\left(\mathrm{U}_{3}\right)=1,5 \mathrm{~g} / \mathrm{kgBB} \times 54 \mathrm{~kg}=81 \mathrm{~g}$

Batas bawah $\left(\mathrm{L}_{3}\right)=0,8 \frac{\mathrm{g}}{\mathrm{kgBBI}} \times 54 \mathrm{~kg}=43,2 \mathrm{~g}$

c. Kandungan Lemak

Batas atas $\left(U_{4}\right)=25 \% \times \frac{1890}{9}=52,5 \mathrm{~g}$

Batas bawah $\left(\mathrm{L}_{4}\right)=20 \% \times \frac{1890}{9}=42 \mathrm{~g}$

Berdasarkan standar diet stroke pada RSUD Klungkung, penderita diberikan menu diet stroke IIB. Pada pembuatan menu diet, pemberian makan akan dibagi menjadi enam tahap, yaitu sarapan, selingan pagi, makan siang, selingan sore, makan malam dan selingan malam. Perencanaan menu diet Stroke IIB 1.890 kkal dengan menggunakan Metode Bahan Makanan Penukar selama tiga hari ditunjukkan pada Tabel 1.

\subsection{Pembentukan Model Goal Programming}

Pembentukan model goal programming diawali dengan menentukan variabel keputusan. variabel keputusan dalam penelitian ini adalah jumlah bahan makanan dalam satuan gram yang digunakan untuk menyusun menu diet stroke IIB dalam satu hari. Selanjutnya disusun fungsi kendala dengan menggunakan batas-batas yang sebelumnya telah dihitung. Fungsi kendala yang digunakan antara lain fungsi kendala energi, kendala karbohidrat, kendala lemak, kendala protein dan kendala bahan pangan.

\section{a. Fungsi Kendala Energi/kalori}

$$
\begin{array}{r}
\sum_{j=1}^{7} E_{1 j} x_{1 j}+\sum_{i=2,4}^{4} \sum_{j=1}^{3} E_{i j} x_{i j}+\sum_{i=3,5}^{5} \sum_{j=1}^{6} E_{i j} x_{i j} \\
+\sum_{j=1}^{2} E_{6 j} x_{6 j}-A_{1}+B_{1}=U_{1}
\end{array}
$$

Dengan $E_{i j}$ menyatakan kandungan energi per satu gram bahan pangan pada varian makanan ke-j untuk penyajian makanan ke-i dan $U_{1}$ sebagai batasan dari energi

Tabel 1. Menu Diet Stroke Hari 1 dengan Metode

\begin{tabular}{|c|c|c|}
\hline \multirow{2}{*}{$\begin{array}{c}\text { Waktu } \\
\text { Pemberian }\end{array}$} & \multicolumn{2}{|c|}{ Hari 1} \\
\hline & Bahan Makanan & Berat (g) \\
\hline \multirow{6}{*}{ Sarapan } & Nasi & 100,0 \\
\hline & Ikan segar & 40,0 \\
\hline & Bayam merah & 50,0 \\
\hline & Gula Pasir & 10,0 \\
\hline & Tepung Susu Skim & 20,0 \\
\hline & Minyak jagung & 10,0 \\
\hline \multirow{2}{*}{$\begin{array}{l}\text { Selingan } \\
\text { Pagi }\end{array}$} & Maizena & 20,0 \\
\hline & Gula Pasir & 20,0 \\
\hline \multirow{6}{*}{ Makan Siang } & Nasi & 150,0 \\
\hline & Telur ayam & 55,0 \\
\hline & Tempe & 50,0 \\
\hline & Daun pepaya & 50,0 \\
\hline & Jambu biji & 100,0 \\
\hline & Minyak jagung & 10,0 \\
\hline \multirow{2}{*}{$\begin{array}{l}\text { Selingan } \\
\text { Sore }\end{array}$} & Gula pasir & 10,0 \\
\hline & Tepung Susu skim & 20,0 \\
\hline \multirow{6}{*}{$\begin{array}{l}\text { Makan } \\
\text { Malam }\end{array}$} & Nasi & 150,0 \\
\hline & Otak & 60,0 \\
\hline & Oncom & 40,0 \\
\hline & Daun singkong & 50,0 \\
\hline & Pepaya & 110,0 \\
\hline & Minyak jagung & 10,0 \\
\hline Slng Mlm & Gula pasir & 10,0 \\
\hline \multicolumn{2}{|c|}{ Total energi (kkal) } & $1.845,0$ \\
\hline \multicolumn{2}{|c|}{ Total karbohidrat (g) } & 309,0 \\
\hline \multicolumn{2}{|c|}{ Total protein $(\mathrm{g})$} & 67,1 \\
\hline \multicolumn{2}{|c|}{ Total lemak (g) } & 48,0 \\
\hline
\end{tabular}
BMP 
Tabel 2. Menu Diet Stroke Hari 2 dengan Metode BMP

\begin{tabular}{|c|c|c|}
\hline \multirow{2}{*}{$\begin{array}{c}\text { Waktu } \\
\text { Pemberian }\end{array}$} & \multicolumn{2}{|c|}{ Hari 2} \\
\hline & Bahan Makanan & Berat (g) \\
\hline \multirow{6}{*}{ Pagi } & Nasi & 100,0 \\
\hline & Ayam tanpa kulit & 40,0 \\
\hline & Daun katuk & 50,0 \\
\hline & Gula Pasir & 10,0 \\
\hline & Tepung Susu Skim & 20,0 \\
\hline & Minyak jagung & 10,0 \\
\hline \multirow{2}{*}{$\begin{array}{c}\text { Selingan } \\
\text { Pagi }\end{array}$} & Maizena & 20,0 \\
\hline & Gula Pasir & 20,0 \\
\hline \multirow{6}{*}{ Siang } & Nasi & 150,0 \\
\hline & Bakso & 170,0 \\
\hline & Oncom & 40,0 \\
\hline & Daun singkong & 50,0 \\
\hline & Jeruk & 110,0 \\
\hline & Minyak jagung & 10,0 \\
\hline \multirow{2}{*}{$\begin{array}{l}\text { Selingan } \\
\text { Sore }\end{array}$} & Gula Pasir & 10,0 \\
\hline & Susu skim & 20,0 \\
\hline \multirow{6}{*}{ Malam } & Nasi & 150,0 \\
\hline & Babat & 40,0 \\
\hline & Tempe & 50,0 \\
\hline & Bayam merah & 50,0 \\
\hline & Nanas & 95,0 \\
\hline & Minyak jagung & 10,0 \\
\hline Slng Mlm & Gula pasir & 10,0 \\
\hline \multicolumn{2}{|c|}{ Total energi (kkal) } & $1.820,0$ \\
\hline \multicolumn{2}{|c|}{ Total karbohidrat (g) } & 309,0 \\
\hline \multicolumn{2}{|c|}{ Total protein $(\mathrm{g})$} & 67,1 \\
\hline \multicolumn{2}{|c|}{ Total lemak $(\mathrm{g})$} & 45,0 \\
\hline
\end{tabular}

Tabel 3. Menu Diet Stroke Hari 3 dengan Metode BMP

\begin{tabular}{|c|c|c|}
\hline \multirow{2}{*}{$\begin{array}{c}\text { Waktu } \\
\text { Pemberian }\end{array}$} & \multicolumn{2}{|c|}{ Hari 3} \\
\hline & Bahan Makanan & Berat (g) \\
\hline \multirow{6}{*}{ Pagi } & Nasi & 100,0 \\
\hline & Telur ayam & 55,0 \\
\hline & Taoge & 50,0 \\
\hline & Gula Pasir & 10,0 \\
\hline & Tepung Susu Skim & 20,0 \\
\hline & Minyak jagung & 10,0 \\
\hline \multirow{2}{*}{$\begin{array}{c}\text { Selingan } \\
\text { Pagi }\end{array}$} & Maizena & 20,0 \\
\hline & Gula Pasir & 20,0 \\
\hline \multirow{6}{*}{ Siang } & Nasi & 150,0 \\
\hline & Hati ayam & 30,0 \\
\hline & Tempe & 50,0 \\
\hline & Bayam merah & 50,0 \\
\hline & Pepaya & 110,0 \\
\hline & Minyak jagung & 10,0 \\
\hline \multirow{2}{*}{$\begin{array}{l}\text { Selingan } \\
\text { Sore }\end{array}$} & Gula Pasir & 10,0 \\
\hline & Susu skim & 20,0 \\
\hline \multirow{6}{*}{ Malam } & Nasi & 150,0 \\
\hline & Usus sapi & 50,0 \\
\hline & Pete & 55,0 \\
\hline & Daun pepaya & 50,0 \\
\hline & Mangga & 90,0 \\
\hline & Minyak jagung & 10,0 \\
\hline Slng Mlm & Gula pasir & 10,0 \\
\hline \multicolumn{2}{|c|}{ Total energi (kkal) } & $1.857,5$ \\
\hline \multicolumn{2}{|c|}{ Total karbohidrat (g) } & 306,5 \\
\hline \multicolumn{2}{|c|}{ Total protein $(\mathrm{g})$} & 66,1 \\
\hline \multicolumn{2}{|c|}{ Total lemak (g) } & 51,0 \\
\hline
\end{tabular}




\section{b. Fungsi Kendala Karbohidrat, Lemak dan Protein}

Untuk fungsi kendala karbohidrat, protein dan lemak nilainya berada pada interval tertentu. Hasil penyelesaian yang diharapkan tidak menyimpang di bawah nilai batas bawah atau di atas batas atas. Oleh karena itu, penyimpangan tersebut harus diminimumkan dengan menghadirkan variabel deviasional atas $A_{i}$ dan variable deviasional bawah $B_{i}$. Fungsi kendala karbohidrat, protein dan lemak ditunjukkan sebagai berikut:

- Fungsi Kendala Karbohidrat

i. $\sum_{j=1}^{7} K_{1 j} x_{1 j}+\sum_{i=2,4}^{4} \sum_{j=1}^{3} K_{i j} x_{i j}+$ $\sum_{i=3,5}^{5} \sum_{j=1}^{6} K_{i j} x_{i j}+\sum_{j=1}^{2} K_{6 j} x_{6 j}-$ $A_{2} \leq U_{2}$

ii. $\sum_{j=1}^{7} K_{1 j} x_{1 j}+\sum_{i=2,4}^{4} \sum_{j=1}^{3} K_{i j} x_{i j}+$ $\sum_{i=3,5}^{5} \sum_{j=1}^{6} K_{i j} x_{i j}+\sum_{j=1}^{2} K_{6 j} x_{6 j}+$ $B_{2} \geq L_{2}$

Dengan $K_{i j}$ menyatakan kandungan karbohidrat per satu gram bahan pangan pada varian makanan ke-j untuk penyajian makanan ke-i

- Fungsi Kendala Protein

i. $\sum_{j=1}^{7} P_{1 j} x_{1 j}+\sum_{i=2,4}^{4} \sum_{j=1}^{3} P_{i j} x_{i j}+$ $\sum_{i=3,5}^{5} \sum_{j=1}^{6} P_{i j} x_{i j}+\sum_{j=1}^{2} P_{6 j} x_{6 j}-$ $A_{3} \leq U_{3}$

ii. $\sum_{j=1}^{7} P_{1 j} x_{1 j}+\sum_{i=2,4}^{4} \sum_{j=1}^{3} P_{i j} x_{i j}+$ $\sum_{i=3,5}^{5} \sum_{j=1}^{6} P_{i j} x_{i j}+\sum_{j=1}^{2} P_{6 j} x_{6 j}+$ $B_{3} \geq L_{3}$

Dengan $P_{i j}$ menyatakan kandungan protein per satu gram bahan pangan pada varian makanan ke-j untuk penyajian makanan ke-i

- Fungsi Kendala Lemak

i. $\sum_{j=1}^{7} F_{1 j} x_{1 j}+\sum_{i=2,4}^{4} \sum_{j=1}^{3} F_{i j} x_{i j}+$ $\sum_{i=3,5}^{5} \sum_{j=1}^{6} F_{i j} x_{i j}+\sum_{j=1}^{2} F_{6 j} x_{6 j}-$ $A_{4} \leq U_{4}$

ii. $\sum_{j=1}^{7} F_{1 j} x_{1 j}+\sum_{i=2,4}^{4} \sum_{j=1}^{3} F_{i j} x_{i j}+$ $\sum_{i=3,5}^{5} \sum_{j=1}^{6} F_{i j} x_{i j}+\sum_{j=1}^{2} F_{6 j} x_{6 j}+$ $B_{4} \geq L_{4}$

Dengan $F_{i j}$ menyatakan kandungan lemak per satu gram bahan pangan pada varian makanan ke-j untuk penyajian makanan kei

\section{c. Fungsi Kendala Jumlah Bahan Pangan}

Untuk $m=5,6, \ldots, 10$

$$
\begin{aligned}
& x_{i j}-A_{m j} \leq U_{i j} \\
& x_{i j}+B_{m j} \geq L_{i j}
\end{aligned}
$$

Ketentuan selang batas yang disarankan adalah dengan mengurangi 5 gram dari berat bahan makanan awal untuk batas bawah dan batas atasnya naik 5 gram dari berat bahan makanan awal. Berat bahan makanan awal yang dimaksud adalah berat bahan makanan dari menu diet Stroke IIB yang disusun menggunakan metode BMP.

Keterangan:

$i$ : indeks yang menunjukkan waktu pemberian makanan, misalkan $i=1$ berarti pada saat sarapan, dst.

$j \quad$ : indeks yang menunjukkan banyaknya variasi pada makanan

$x_{i j} \quad$ : variable keputusan yang menunjukkan jumlah bahan makanan (gr) pada varian makanan ke-j untuk penyajian makanan ke-i

$U_{i j} \quad$ : batas atas jumlah bahan makanan pada varian makanan ke-j untuk penyajian makanan ke-i

$L_{i j} \quad$ : batas bawah jumlah bahan makanan pada varian makanan ke-j untuk penyajian makanan ke-i

$A_{m j} \quad$ : deviasi atas ke-mj terhadap tujuan $U_{i j}$

$B_{m j}$ : deviasi bawah ke-mj terhadap tujuan $L_{i j}$

\section{d. Fungsi Tujuan}

Tujuan yang hendak dicapai dalam penyelesaian kasus ini adalah meminimumkan penyimpangan terhadap kebutuhan energi/kalori, penyimpangan kandungan zat gizi (karbohidrat, protein dan lemak) dan penyimpangan kebutuhan bahan pangan. Oleh karena itu, fungsi tujuannya adalah:

$$
\begin{aligned}
Z= & \sum_{i=1}^{4}\left(A_{i}+B_{i}\right)+\sum_{m=5,7,9}^{9} \sum_{j=1}^{6}\left(A_{m j}+B_{m j}\right)+ \\
& \sum_{m=6,8}^{8} \sum_{j=1}^{2}\left(A_{m j}+B_{m j}\right)+\sum_{j=1}^{2}\left(A_{10 . j}+B_{10 . j}\right)
\end{aligned}
$$




\subsection{Penyelesaian Goal Programming dan Interpretasi Hasil}

Hasil perhitungan dengan software LINGO 17 secara terperinci dan ringkas ditunjukkan pada Tabel 4, Tabel 5, dan Tabel 6.

Tabel 4. Menu Diet Stroke Hari 1 dengan Metode Goal Programming

\begin{tabular}{|c|c|c|}
\hline \multirow{2}{*}{$\begin{array}{c}\text { Waktu } \\
\text { Pemberian }\end{array}$} & \multicolumn{2}{|l|}{ Hari 1} \\
\hline & Bahan Makanan & Berat $(g)$ \\
\hline \multirow{6}{*}{ Pagi } & Nasi & 105,0 \\
\hline & Ikan & 45,0 \\
\hline & Bayam merah & 45,0 \\
\hline & Gula Pasir & 15,0 \\
\hline & Tepung Susu Skim & 25,0 \\
\hline & Minyak jagung & 15,0 \\
\hline \multirow{2}{*}{$\begin{array}{l}\text { Selingan } \\
\text { Pagi }\end{array}$} & Maizena & 25,0 \\
\hline & Gula Pasir & 19,6 \\
\hline \multirow{6}{*}{ Siang } & Nasi & 155,0 \\
\hline & Telur ayam & 50,0 \\
\hline & Tempe & 45,0 \\
\hline & Daun pepaya & 45,0 \\
\hline & Jambu biji & 95,0 \\
\hline & Minyak jagung & 5,3 \\
\hline \multirow{2}{*}{$\begin{array}{l}\text { Selingan } \\
\text { Sore }\end{array}$} & Gula pasir & 5,0 \\
\hline & Tepung Susu skim & 25,0 \\
\hline \multirow{6}{*}{ Malam } & Nasi & 155,0 \\
\hline & Otak & 55,0 \\
\hline & Oncom & 35,0 \\
\hline & Daun singkong & 45,0 \\
\hline & Pepaya & 105,0 \\
\hline & Minyak jagung & 5,0 \\
\hline Slng Mlm & Gula pasir & 15,0 \\
\hline \multicolumn{2}{|c|}{ Total energi (kkal) } & $1.890,0$ \\
\hline \multicolumn{2}{|c|}{ Total karbohidrat (g) } & 325,3 \\
\hline \multicolumn{2}{|c|}{ Total protein $(\mathrm{g})$} & 69,7 \\
\hline \multicolumn{2}{|c|}{ Total lemak $(\mathrm{g})$} & 42,1 \\
\hline
\end{tabular}

Tabel 5. Menu Diet Stroke Hari 2 dengan Metode Goal Programming

\begin{tabular}{|c|c|c|}
\hline \multirow{2}{*}{$\begin{array}{c}\text { Waktu } \\
\text { Pemberian }\end{array}$} & \multicolumn{2}{|l|}{ Hari 2} \\
\hline & Bahan Makanan & Berat (g) \\
\hline \multirow{6}{*}{ Pagi } & Nasi & 105,0 \\
\hline & Ayam tanpa kulit & 45,0 \\
\hline & Daun katuk & 45,0 \\
\hline & Gula Pasir & 13,8 \\
\hline & Tepung Susu Skim & 25,0 \\
\hline & Minyak jagung & 15,0 \\
\hline \multirow{2}{*}{$\begin{array}{c}\text { Selingan } \\
\text { Pagi }\end{array}$} & Maizena & 25,0 \\
\hline & Gula Pasir & 15,0 \\
\hline \multirow{6}{*}{ Siang } & Nasi & 155,0 \\
\hline & Bakso & 165,0 \\
\hline & Oncom & 45,0 \\
\hline & Daun singkong & 45,0 \\
\hline & Jeruk & 105,0 \\
\hline & Minyak jagung & 6,1 \\
\hline \multirow{2}{*}{$\begin{array}{l}\text { Selingan } \\
\text { Sore }\end{array}$} & Gula Pasir & 5,0 \\
\hline & Susu skim & 25,0 \\
\hline \multirow{6}{*}{ Malam } & Nasi & 155,0 \\
\hline & Babat & 45,0 \\
\hline & Tempe & 55,0 \\
\hline & Bayam merah & 45,0 \\
\hline & Nanas & 90,0 \\
\hline & Minyak jagung & 5,0 \\
\hline Slng Mlm & Gula pasir & 15,0 \\
\hline \multicolumn{2}{|c|}{ Total energi (kkal) } & $1.890,0$ \\
\hline \multicolumn{2}{|c|}{ Total karbohidrat (g) } & 321,4 \\
\hline \multicolumn{2}{|c|}{ Total protein $(\mathrm{g})$} & 73,8 \\
\hline \multicolumn{2}{|c|}{ Total lemak (g) } & 42,1 \\
\hline
\end{tabular}


Tabel 6. Menu Diet Stroke Hari 3 dengan Metode Goal Programming

\begin{tabular}{|c|c|c|}
\hline \multirow{2}{*}{$\begin{array}{c}\text { Waktu } \\
\text { Pemberian }\end{array}$} & \multicolumn{2}{|l|}{ Hari 3} \\
\hline & Bahan Makanan & Berat (g) \\
\hline \multirow{6}{*}{ Pagi } & Nasi & 105,0 \\
\hline & Telur ayam & 50,0 \\
\hline & Taoge & 45,0 \\
\hline & Gula Pasir & 15,0 \\
\hline & Tepung Susu Skim & 15,0 \\
\hline & Minyak jagung & 15,0 \\
\hline \multirow{2}{*}{ Slng Pagi } & Maizena & 15,0 \\
\hline & Gula Pasir & 25,0 \\
\hline \multirow{6}{*}{ Siang } & Nasi & 148,7 \\
\hline & Hati ayam & 25,0 \\
\hline & Tempe & 55,0 \\
\hline & Bayam merah & 45,0 \\
\hline & Pepaya & 105,0 \\
\hline & Minyak jagung & 12,7 \\
\hline \multirow{2}{*}{$\begin{array}{l}\text { Selingan } \\
\text { Sore }\end{array}$} & Gula Pasir & 15,0 \\
\hline & Susu skim & 15,0 \\
\hline \multirow{6}{*}{ Malam } & Nasi & 145,0 \\
\hline & Usus sapi & 45,0 \\
\hline & Pete & 60,0 \\
\hline & Daun pepaya & 45,0 \\
\hline & Mangga & 85,0 \\
\hline & Minyak jagung & 5,0 \\
\hline Slng Mlm & Gula pasir & 15,0 \\
\hline \multicolumn{2}{|c|}{ Total energi (kkal) } & $1.890,0$ \\
\hline \multicolumn{2}{|c|}{ Total karbohidrat (g) } & 319,9 \\
\hline \multicolumn{2}{|c|}{ Total protein $(\mathrm{g})$} & 60,3 \\
\hline \multicolumn{2}{|c|}{ Total lemak $(\mathrm{g})$} & 52,5 \\
\hline
\end{tabular}

Berdasarkan hasil perhitungan dengan LINGO, diperoleh bahwa variabel deviasi yaitu variabel deviasi atas $\left(A_{i}\right)$ dan variabel deviasi bawah $\left(B_{i}\right)$ untuk penyusunan menu diet selama tiga hari adalah 0 . Hal ini menunjukkan bahwa hasil yang diperoleh sudah memenuhi sasaran. Selain itu untuk membuktikannya dapat juga dilihat dari kandungan karbohidrat, protein dan lemak dari hasil baru yang sudah memenuhi sasaran kandungan energi dan zat gizinya sudah memenuhi angka yang direkomendasikan. Kandungan energi yang dihasilkan per harinya dari perancangan menu diet stroke IIB tersebut sudah memenuhi angka yang direkomendasikan yaitu 1.890 kkal. Selanjutnya, hasil untuk kandungan karbohidrat per harinya sudah berada di dalam selang batas 283,5-330,75. Hasil perhitungan untuk kandungan protein per harinya sudah berada di dalam selang batas 43,2-81 gram. Lebih lanjut lagi, untuk hasil perhitungan kandungan lemak per harinya semuanya berada di selang batas 42-52,5 gram. Oleh karena itu, hasil yang diperoleh melalui perhitungan menggunakan metode goal programming, sudah memenuhi sasaran kandungan energi, karbohidrat, protein dan lemak yang direkomendasikan.

\subsection{Persentase Kesesuaian Kandungan Energi dari Penyusunan Menu Diet Stroke IIB terhadap Kandungan Energi Standar}

Persentase jumlah energi/kalori dari penyusunan menu diet stroke IIB terhadap kandungan energi yang digunakan di RSUD Klungkung diperoleh dengan cara membagi total energi dari menu diet Stroke IIB dengan total energi yang direkomendasikan pada Standar Diet RSUD Klungkung (1.890 kkal), kemudian hasilnya dikalikan dengan $100 \%$. Tabel 7 menunjukkan persentase jumlah energi/kalori dari penyusunan menu diet stroke IIB baik menggunakan metode bahan makanan penukar dan metode goal programming terhadap kandungan energi yang digunakan di RSUD Klungkung.

Tabel 7. Persentase Kesesuaian Kandungan Energi Terhadap Kandungan Energi Standar.

\begin{tabular}{|l|r|r|}
\hline & $\begin{array}{c}\text { Metode Bahan } \\
\text { Makanan } \\
\text { Penukar (BMP) }\end{array}$ & $\begin{array}{c}\text { Metode Goal } \\
\text { programming } \\
\text { (GP) }\end{array}$ \\
\hline Hari 1 & $97,6 \%$ & $100 \%$ \\
Hari 2 & $96,3 \%$ & $100 \%$ \\
Hari 3 & $98,3 \%$ & $100 \%$ \\
\hline
\end{tabular}

Hasil perhitungan pencapaian zat gizi dari perencanaan menu diet dengan menggunakan metode BMP menunjukkan persentase yang berbeda dengan standarnya. Persentase kesesuaian kandungan energi dari diet Stroke IIB dengan menggunakan metode BMP terhadap kandungan energi yang disarankan di RSUD Klungkung berkisar antara 96,3\% sampai 98,3\%. Sedangkan dengan menggunakan metode goal programming, persentase kesesuaian kandungan energinya untuk hari ke-1, hari ke-2, dan hari ke-3 menunjukkan nilai $100 \%$ terhadap kandungan energi standar di RSUD Klungkung. Hal ini 
menunjukkan bahwa menu diet dengan metode BMP belum memenuhi angka energi yang dianjurkan. Namun dengan menggunakan metode goal programming dapat memenuhi angka energi yang dianjurkan berdasarkan standar diet stroke IIB RSUD Klungkung.

\section{SIMPULAN DAN SARAN}

\subsection{Simpulan}

Hasil porsi makanan yang diperoleh dari penyusunan menu diet stroke IIB dengan menggunakan metode goal programming selama tiga hari sudah dapat memenuhi sasaran energi dan kandungan gizi (karbohidrat, protein dan lemak) yang direkomendasikan pada standar diet Stroke RSUD Klungkung. Persentase kesesuaian total kandungan energi dari penyusunan menu diet stroke IIB terhadap kandungan energi standar dari RSUD Klungkung, dengan menggunakan metode goal programming adalah $100 \%$ untuk hari ke-1, $100 \%$ untuk hari ke-2, dan $100 \%$ untuk hari ke3. Jadi, penggunaan metode goal programming dalam penyusunan menu diet stroke IIB telah memperlihatkan hasil yang lebih baik dibandingkan dengan menggunakan metode bahan makanan penukar.

\subsection{Saran}

Untuk penelitian selanjutnya yang akan melakukan penyusunan menu diet dengan menerapkan metode goal programming, penulis menyarankan untuk menambah kandungan gizi lainnya sebagai fungsi kendalanya, seperti menambah zat gizi natrium, kolesterol, dan zat gizi lainnya dan dapat menggunakan pembobotan dalam penyusunan menu makanan menggunakan metode goal programming

\section{DAFTAR PUSTAKA}

Almatsier, S. 2004. Penuntun Diet (20th ed.). Jakarta: PT Gramedia Pustaka Utama.

Dhoruri, A., Lestari, D., \& Ratnasari, E. 2017. Menu variations for diabetes mellitus patients using Goal Programming model. AIP Conference Proceedings, 1867(August). https://doi.org/10.1063/1.4994418

Kemenkes RI. 2013. Laporan Hasil Riset Kesehatan Dasar (Riskesdas) Indonesia tahun 2013. Jakarta.

Kemenkes RI. 2018. Laporan Hasil Riset Kesehatan Dasar (Riskesdas) Indonesia tahun 2018. Riset Kesehatan Dasar 2018. Jakarta. Retrieved from http://labdata.litbang.depkes.go.id/ccount/cl ick.php?id=19

Kemenkes RI. 2019. Penyakit Tidak Menular (PTM) Penyebab Kematian Terbanyak di Indonesia. Retrieved November 11, 2019, from

https://www.kemkes.go.id/article/view/163 7/penyakit-tidak-menular-ptm-penyebabkematian-terbanyak-di-indonesia.html

Mustafa, W. F., Djamal, E. C., \& Yuniarti, R. 2017. Optimalisasi Menu Makan Diet Sehat Menggunakan Algoritma Genetika, (September), 50-54.

PERSAGI, \& ADI. 2019. Penuntun Diet dan Terapi Gizi (4th ed.). Jakarta: Penerbit Buku Kedokteran EGC.

Siswanto. 2007. Operation Research Jilid I. (T. Prasetyo \& Y. Sumiharti, Eds.) (1st ed.). Jakarta: Penerbit Erlangga.

WHO. 2016. The Global Burden of Cerebrovascular Disease. Retrieved from https://www.who.int/leishmaniasis/burden/ en/ 